\title{
THE ROLE OF MANAGEMENT ACCOUNTING IN THE DECISION MAKING PROCESS: CASE STUDY CARAŞ SEVERIN COUNTY
}

\author{
Adela Breuer ${ }^{1}$ \\ Mihaela Lesconi Frumuşanu ${ }^{2}$ \\ Andra Manciu ${ }^{3}$
}

\begin{abstract}
Management accounting is an important part of the economic information system, with a key role in decision making, whether we talk about small and medium enterprises or large companies. However, management accounting is superficially treated in most economic entities, there are entities in which professional accountants consider management accounting as optional, as shown in the survey performed in Carass Severin County, querying 50 economic entities from the three categories (microenterprises, SMEs and large companies) and processing the results in SPSS.
\end{abstract}

Keywords: management accounting, economic information system, decision making, management, cost

JEL Codes: M41

\section{Introduction}

Information and the information system are terms with increasing impacts on the enterprises, invading the models and the management analysis fields. Exactly as in any other information system, the economic information system contains news and information from different fields, but most of them derive from the economic database.

The most representative sources of economic data and information are (Ovidia, 2013):

- The economic planning, which provides economic informational planning and business prognosis data, their share being of $28 \%$ of the total economic information;

- The economic database which provides effective information data, representing $70 \%$ of the total economic information, distributed as follows:

- 46-50\% information provided by accounting;

- $9-13 \%$ information provided by the economic-social statistics;

- $11 \%$ of the information is provided by the active database;

- Other sources represent the rest of the $2 \%$ percentage.

Hence, the information of the economic information system are mostly (70\%) provided by the economic evidence/database, mentioning that most part of information in organizations include accounting information (Zare and Shahsavari, 2012: 5-10), a statement sustained by the fact that the accounting information systems includes components and elements of an organization that provides informations for users by processing financial events (Zare et.all, 2012: 32-38).

Based on the accounting information function, which is to provide information in order to substantiate decisions, and considering the two components of accounting (financial and managerial accounting), we can assert that accounting has an internal information function (for the enterprise management) and an external one (for the third parties). Internal decision-making and analysis of causeand-effect relationships can require very specific models and accounting information (Eierle and

\footnotetext{
1 "Eftimie Murgu” University of Resita, Romania, e-mail: adela1209@yahoo.com

2 "Eftimie Murgu" University of Resita, Romania, e-mail: mihaelafrumusanu@yahoo.com

${ }^{3}$ West University Timi $\square$ oara, Romania, e-mail: andramanciu@yahoo.com
} 
Wolfgang, 2013). Because managers should obtain high-quality and suitable information from formal and informal channels for decision-making (Zare et.all, 2013: 589), and because financial accounting information is regarded as not being adequate (Eierle and Wolfgang, 2013), the managerial accountingprovided information underlie the decision making both inside and outside the enterprise

According to Law 82/1991, accounting in Romania is organized in double circuit, financial accounting and management accounting. The formal dualism or the accounting system in two circuits is an organization of the accounting system that allows a dissociation between the financial accounting, which is subject for standardization, and the managerial accounting, for which the following rule is applied "no admittance except on business" (Diaconu, 2002: 23) and which ensures the advantage of high accounting information confidentiality (Crețu and Iova, 2011).

\section{Studies made in the field of Managerial Accounting - Literature review}

Accounting is an information system and managers should obtain high-quality and suitable information from formal and informal channels for decision-making (Zare et al.,2013)

At the beginning of ' 90 managerial accounting was reconsidered, we witnessed a separation of the two components of the accounting system (financial and managerial accounting) (Cardo $\square$ and Pete, 2011).

Assuming that each entity has the right to create its own information system (own communication channels, responsible persons, etc), then we can characterize the information system of the management accounting as being the ,sum of procedures, means and regulations that are used for the collection, processing, transmission, use and storage of the accounting information without being disclosed to the public without disclosure" (Briciu and Teiu $\square$ an, 2006).

In order to prove that the management accounting belongs to the accounting information system, we will analyse the participation of this accounting to the functioning of the accounting system. Thus, management accounting provides a detailed overview of each activity, whence the denomination of analytic accounting (Budugan et al., 2007: 10), following the collection and distribution of expenses on activities, as well as the calculation of costs from the production, trade, service providing and financial units and from other fields of activity (OMFP nr.1826/2003), thus providing data necessary for the users of the accounting information.

In a general sense, managerial accounting is an integral part of management that deals with identifying, presenting and interpreting information used for strategies, decision making, resource optimization, employee information, asset protection planning and control of activities, information of associates or other external information users. ( Briciu, and Căpuşneanu, 2011: 57-68)

Professor Oprea Călin considers that management accounting „has as main objective the reflection upon all the operations of cost collection and allocation by destinations, i.e. products, works, services, orders, manufacture phases, activities, departments, etc, the settlement of the obtained production, as well as the calculation of the production cost for the manufactured products, the executed works and the provided services, including the production-in-progress (Călin, 2002: 15).

Professor Henry Bouquin proposes the following definition of management accounting: ,a system of accounting information that intends to help managers and influences behaviours by shaping the relations between the consumed allotted resources and the aimed finality" (Bouquin, 2004: 11-12).

Managers direct the future and constantly report it to the present (Bouquin, 2004: 45), and management accounting provides information about the future and about what is going to happen (Diaconu, 2006). The need for information is ,caused" usually by the decisions that must be taken. Either way, information must regard the three criteria set by Emery (Emery, 1969: 91):

1) information is valuable for the manager if it helps reduce the future uncertainty;

2) additional information is valuable if it can affect the respective decision;

3 ) information is valuable if it helps to ,sensitively" change the consequences of a decision. 
Presenting the management accounting in service of the decision requires the need to describe the conception of this decision. Herbert Simon, Nobel Prize winner for economics, author of the famous works dedicated to the decision systems, presented in an inquiry what managers expect from the management accounting (Simon et al., 1978):

- To allow an observation (score keeping): ,,are things good or bad?”;

- To draw attention (attention directing): ,what problems should be of interest?”;

- To help solving problems (problem solving): „from the different solutions, which one is the best?".

In fact, management accounting, oriented especially towards providing information to managers, being considered ,an informational tool necessary to the management for taking decisions, to maximize profitability" (Dumitru and Calu, 2008) is folded up the three key functions of management, as follows:

- planning: management accounting helps in setting future goals (strategic planning) providing information necessary in taking decision on the adopted production systems, the company's price policy, the trade policy, and the appreciation of the invested capital;

- organization: the interaction of the management accounting and the organizational process is presented as follows: the identification of the organizational structure and a better understanding of the methods for determining the authority and the distribution of responsibility are essential in the determination of information in an economic entity. Instead, the necessary information defines the structure of the collected data and processing activities from the management accounting information system (Oprea, 1994: 42);

- control: management accounting sustains the verification process of the method and the extent to which the proposed objectives have/have not been accomplished, elaborating the reports that should indicate the actual performances opposed to the proposed objectives. The control (Oprea, 1994: 23), as basic function of the management in an economic organization, implies monitoring the implementation of the policies, the evaluation of performances and the correction of any abnormalities, while management accounting, as a tool of the management control, provides information for studies and judgements that allow the analysis of any deviations from the budget and the right decision-making. Hence, management accounting ,assists" the control function of the management identifying the activities with ,problems” in a company.

Being oriented from being a scorekeeper or a bean counter towards an increasingly business oriented role (Warren and Parker, 2009), but also from the provided data, through the performed analysis, management accounting provides information about an entity's internal flows, thus creating, besides the financial accounting, which provides data about external flows, an overall analysis, being a useful instrument in the decision making process (Jarvenpaa, 2009).

In the French literature, management accounting aims to identify the costs, the evaluation of certain elements of the balance sheet, as well as the calculation of the production cost which must be compared to the sales price in order to determine the efficiency of the developed activity, and on the other hand, the cost prediction in order to determine discrepancies from the actual costs (Călin et al., 2008: 10-11)

The normative regulations in our country integrate the management accounting objectives as follows (OMFP nr. 1826/2003):

- entry of operations regarding the cost collection and allocation by destinations, respectively activities, departments, production phases, cost centres, profit centres;

- calculation of the costs of acquisition, production, of incoming goods processing, of executed works, of provided services, of production-in-progress, on-going assets, etc, from production, trade, service providing, financial units.

The information provided by management accounting is of vital importance in the management of a company, because they ensure a good management in decision-making. 


\section{Applied research of Management Accounting in the decision making process in Caras- Severin County}

An economic activity can be conducted correctly if the decision, the implementation and the control of the execution are based on operative, accurate and complete information. In this context, on the one hand, we need an accounting management in order to provide the necessary information, but also an accounting the serves the needs of the manager. (Iacob and Karim, 2013).

The major task of management accounting is to provide information to the management, enabling control over the activities, thus assisting in the decision making, management accounting being the one that ,makes life easier in capitalism, being destined to serve one's need for information" (Diaconu, 2002: 15)

\section{Research method}

Due to the fact that the Romanian legislator, the accounting professionals and the academics constantly emphasize the financial accounting, we thought it necessary to initiate a research theme entitled „Organization of management accounting: mandatory or optional?”; the present paper is integral part of the research theme.

In order to highlight the importance of management accounting in the management process, we elaborated a questionnaire structured in three parts, respectively: legislation in management accounting, the importance given by an entity to the information provided by the management accounting and the last part dedicated to professional accountants. The target group was constituted at the level of Caras Severin County, from 50 economic entities. The research results were centralized using the SPPS program.

In order to launch and analyze the situation existing in Caras Severin County related to the organization and the importance allotted to management accounting, we needed to establish, in the first part of the questionnaire, if the economic entity organizes management accounting, being interested in the explanations received for the two possible situations:

a. If the entity organizes management accounting, we were interested whether this activity is organized with its own resources, with personnel employed with labour contract or if it resorts to other professionals closing temporary work contracts or a contract for the supply of services. If it has its own staff engaged in the organization and development of this activity, we wanted to learn about the stipulations of the job description. With regard to the second situation, the civil or service contracts, the questioned persons had to tell us about the activities conducted by the third parties in the organization of management accounting.

The organization of management accounting was the next point of interest, i.e. if they use specialized computer programs, and which ones, or if they use other methods, like a manual database organization or other electronic means. Information

Because we wanted to make sure that the persons who filled the questionnaires are informed, we asked about the laws/regulations of the respective field, as well as about other resources that can assist them in the organization and development of management accounting. Therefore they were asked to list some legislative regulations related to management accounting, together with some details such as: how accessible are the legal stipulations, if the information contained in the regulations are sufficient and of course their view on the change of the regulations.

b. If the surveyed entity does not organize management accounting, we wanted to know the reasons for not doing so, and of course, how it estimates the cost of the product/work/service provided by the entity it represents.

The second part is dedicated exclusively to those entities that organize management accounting. The first question refers to the used calculation method, being interested in whether they encountered any problems during the implementation period of the cost calculation method/s; if so, we were interested in what solutions they came up with in order to remove the respective obstacles. 
The next point of interest lied in what sources of information they used to implement the calculation method/s. To emphasize the need of greater attention in this field from the legislator, and the academic, the surveyed persons were asked to evaluate the difficulties encountered during the management accounting organization, referring to an incomplete legislation and to disparities in the law, the lack of qualified personnel and of professional training courses, of software, and of course the lack of resources. The problems had to be evaluated in terms of their frequency as well as of their gravity.

We also made an evaluation of some activities specific to management accounting, such as the collection and processing of information, the identification and application of the cost calculation method and the accounting records. And as a direct result, followed the question about the collection of costs in accounts: do they use class 6 „Expense accounts” or class 9 „Management accounts"?

The importance of information provided by the management accounting was also evaluated, asking them to give examples of situations in which this information were useful to the entity's management.

The third part of the questionnaire contains data on the identification of the surveyed persons, data which are dedicated to the analysis of professional accountants. Thus, first we wanted the relation they have with the enterprise: employee or collaborator. Secondly, we were interested in their professional background: accountant with business studies, authorized accountant or chartered accountant. The experience in the accounting field was the third point of interest and of course, which category does the represented entity belong to: microenterprise, SMEs or large taxpayers.

\section{Role of management accounting in decision making: results}

This study presents the results obtained after processing the information contained in the second part of the research topic ,Study on the management accounting organization of the Caras Severin county economic agents", respectively the importance granted to the information provided by management accounting in the management process.

First it should be noted that, from the 50 surveyed entities only 17 organize and conduct management accounting, of which 11 cases involve persons employed, with labour contract, to conduct the management accounting records.

What are the main cost calculation methods implemented within the represented entity?
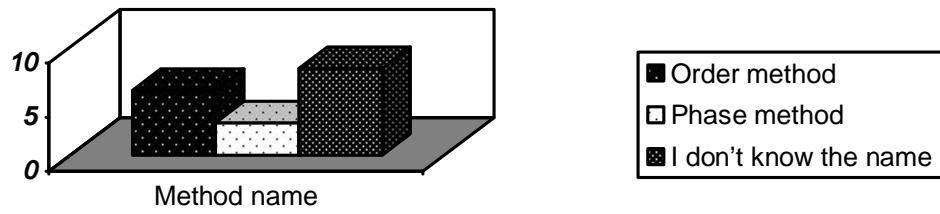

Figure no.1. - Main calculation methods implemented by the surveyed entities

Source: Created by the authors based on the results of the questionnaire;

Because this second part exclusively addresses to the entities that organize and conduct management accounting, we wanted to know first of all the cost calculation method implemented in the represented entity. The answers we received were very surprising, if we take into account that we talked to professional accountants and not with students: 8 accountants of the questioned ones do not know the name of the method, but they could describe what they do.

Specialists in the management accounting field tell us that: managerial accountants have tasks such as work in interdisciplinary teams, involvement in internal processes and decision-making, integration 
of financial and non-financial information at operational and strategic level (Pete and Cardoş, 2011). How can those who lead the financial ,destiny" of an economic entity pertain to the category of professional accountants? And especially where and who is to blame?
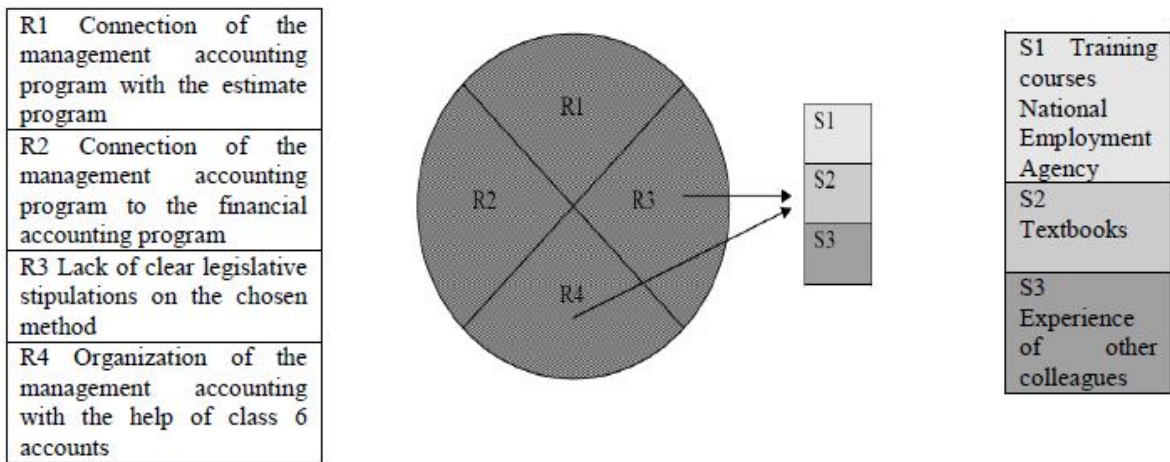

Figure no. 2. - Main problems encountered during the calculation method implementation and their solutions

Source: Created by the authors based on the results of the questionnaire;

In order to organize and conduct the management accounting activity, the professional accountant should apply the correct method of cost calculation, depending on the activity profile of the enterprise. To implement the calculation method, besides the organizational problems, such as connecting the management accounting programs with the financial accounting and the estimate ones, a significant problem is the lack of legislative stipulations related to the calculation method that needs to be implemented depending on the activity profile. Hence, most respondents used textbooks, as well as the training courses provided by the National Employment Agency, or the experience of colleagues. The legislative stipulations suggests as an alternative in the organization of the management accounting records the use of account 6 „Expense accounts” in addition to account 9 ,management account”, without detailing the cost collection and distribution method. And again, professional accountants were forced to turn to other means of information, most handy being the textbooks.

What did you use in order to implement the calculation method?

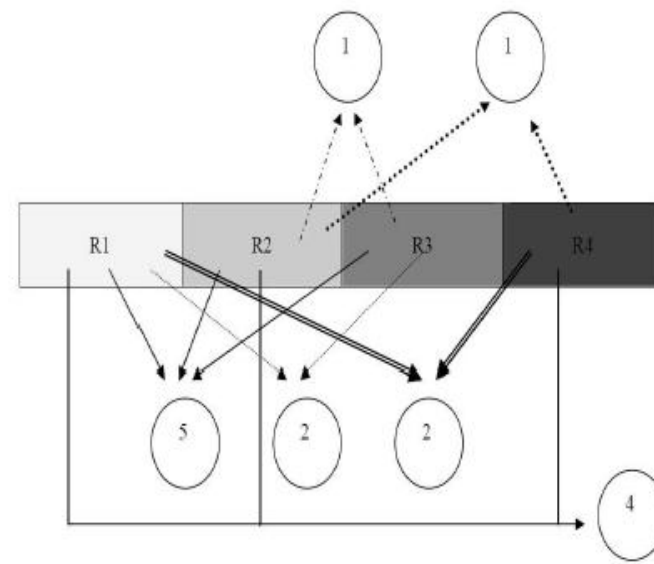

\begin{tabular}{|l|}
\hline R1 Textbooks \\
\hline R2 Training courses \\
\hline $\begin{array}{l}\text { R3 computer software } \\
\text { manuals }\end{array}$ \\
\hline $\begin{array}{l}\text { R4 Similar experience of } \\
\text { other colleagues }\end{array}$ \\
\hline
\end{tabular}

Figure no. 3.- Solutions found by the surveyed entities for the implementation of the calculation methods

Source: Created by the authors based on the results of the questionnaire; 
The accuracy of the result obtained from the application of such methods depends on the correctness of the chosen method. To successfully implement the calculation method, identified as optimal for the represented entity, the professional accountants have turned to various information sources, simultaneously using:

$\checkmark$ Textbooks, training courses and computer software manuals of management accounting;

$\checkmark$ Textbooks and computer software manuals of management accounting;

$\checkmark$ Textbooks and experience of colleagues;

$\checkmark$ Textbooks, training courses and experience of colleagues.

Table no. 1

Evaluation of the difficulties encountered during the management accounting organization

\begin{tabular}{|c|c|c|c|c|c|c|c|c|c|c|}
\hline \multirow{2}{*}{$\begin{array}{c}\text { CRITERION } \\
\text { Scale }\end{array}$} & \multicolumn{5}{|c|}{$\begin{array}{c}\text { IN TERMS } \\
\text { OF THE PROBLEM } \\
\text { FREQUENCY }\end{array}$} & \multicolumn{5}{|c|}{$\begin{array}{c}\text { IN TERMS } \\
\text { OF THE PROBLEM } \\
\text { SEVERITY }\end{array}$} \\
\hline & 1 & 2 & 3 & 4 & 5 & 1 & 2 & 3 & 4 & 5 \\
\hline $\begin{array}{l}\text { Incomplete legislation/ } \\
\text { Legislative disparities }\end{array}$ & & & 7 & 5 & 5 & & & 8 & 6 & 3 \\
\hline Lack of trained personnel & 1 & 9 & 5 & & 2 & 2 & 3 & 9 & 1 & 2 \\
\hline $\begin{array}{l}\text { Lack professional training } \\
\text { programs }\end{array}$ & & 12 & 3 & 1 & 1 & 7 & 3 & 3 & 1 & 3 \\
\hline $\begin{array}{l}\text { Lack of software needed for } \\
\text { this activity }\end{array}$ & 2 & 8 & & 4 & 3 & 2 & 3 & 7 & 3 & 2 \\
\hline Lack of resources & 15 & & 1 & 1 & & 13 & 2 & 2 & & \\
\hline
\end{tabular}

Source: Created by the authors based on the results of the questionnaire;

Due to the striking absence of the management accounting records, we tried to evaluate the problems encountered by those who conduct a management accounting record, in terms of frequency and gravity. Considering a scale of impact from 1 to 5, with 1 the lowest impact and 5 the highest, we observed that the incomplete legislation and the legislative disparities appear in both situations, in the middle of the scale, but we should not neglect the great number of respondents (5) who considered this criterion a very serious one in terms of frequency and (6) respondents in terms of its severity.

The lack of trained personnel, the lack of training programs and of specialized software are not problems to be given special attention when it comes to the frequency of the problems but they are situated at the middle of the scale when referring to the gravity/severity of the problems.

Evaluation of the difficulties encountered in the management accounting activities

\begin{tabular}{||l|c|c|c|c|c||}
\hline \multicolumn{1}{|c|}{ DIFFICULTY } & $\begin{array}{c}\text { VERY } \\
\text { DIFFICULT }\end{array}$ & DIFFICULT & ACCESSIBLE & EASY & $\begin{array}{c}\text { VERY } \\
\text { EASY }\end{array}$ \\
\hline $\begin{array}{l}\text { Information } \\
\text { collection }\end{array}$ & 11 & 9 & 10 & 9 & \\
\hline $\begin{array}{l}\text { Information } \\
\text { processing }\end{array}$ & 7 & 8 & 16 & 8 & 3 \\
\hline $\begin{array}{l}\text { Identification of the } \\
\text { calculation method }\end{array}$ & 9 & 15 & 12 & 17 & \\
\hline $\begin{array}{l}\text { Implementation of } \\
\text { the calculation } \\
\text { method }\end{array}$ & 8 & 14 & & & 39 \\
\hline Accounting record & & & & & \\
\hline
\end{tabular}

Source: Created by the authors based on the results of the questionnaire; 
The organization and the conduction of the management accounting activities involve several steps, such as: the collection of necessary information and their processing, the identification of the calculation method and its implementation and of course the accounting record. The professional accountants consider the process of gathering information a very difficult one while their processing is a very accessible one. Another difficult process is the identification of the calculation method, while its implementation, once established, is again an easy process. Thus, all professional accountants considered the accounting record as easy.

How do you perform the cost collection in specific accounts?
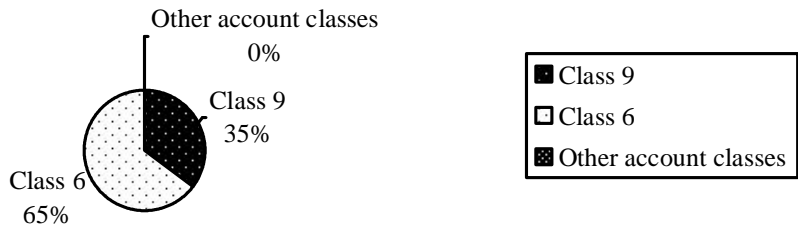

Figure. no. 4. - Cost collection in specific accounts

Source: Created by the authors based on the results of the questionnaire;

The organization of the accounting record in the management accounting offers two alternatives: to organize records using accounts of class 9 ,Management accounts” or those of class 6 ,Expense accounts”. Most professional accountants choose to organize the management accounting record using class 6 .

Do you consider the information provided by management accounting to be:

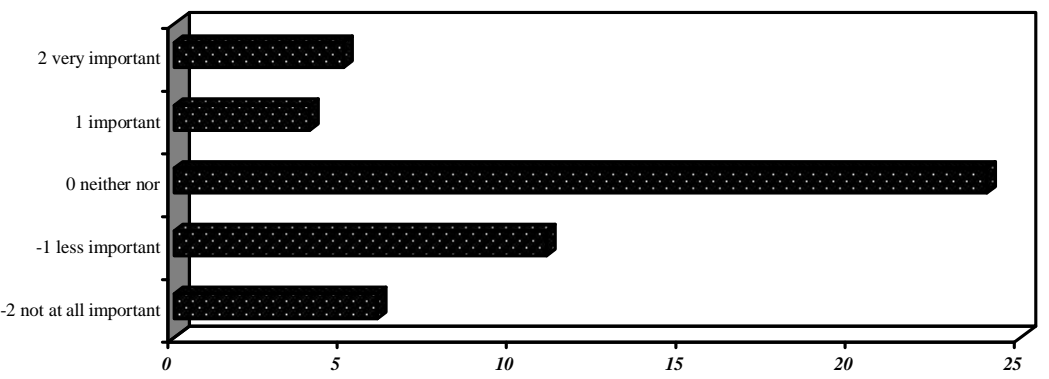

Figure no. 5. - Importance of information provided by management accounting Source: Created by the authors based on the results of the questionnaire;

Professional accountant should not only have tasks and new skills, but also new responsibilities, should not stand waiting in decision making, but to intervene to criticize what was done, to be part of collective action (Briciu and Căpuşneanu, 2011). Unfortunately, this consideration is not confirmed by all the professional accountants. We maintain our affirmation on the management accounting-provided information through the results obtained: of the 50 interviewed persons, half consider that these information are neither important nor unimportant, i.e., in other words, they lack importance. Also, the number of those who considered this information to be less important is considerably higher than the one of those who considers them important or very important.

Table no.2 


\section{Situations in which the information provided by management accounting were useful to the entity management}

\begin{tabular}{|c|c|}
\hline PROFESSIONAL ACCOUNTANTS & $\begin{array}{c}\text { POSITIVE ASPECTS ON THE UTILITY } \\
\text { OF INFORMATION PROVIDED BY } \\
\text { MANAGEMENT ACCOUNTING }\end{array}$ \\
\hline \multirow{2}{*}{ Accountants } & Reducing the costs of a work \\
\hline & Reducing labor costs \\
\hline \multirow{5}{*}{ Authorized accountants } & Reducing labor costs \\
\hline & $\begin{array}{l}\text { Reducing the share of indirect costs in total } \\
\text { costs }\end{array}$ \\
\hline & $\begin{array}{l}\text { Reducing costs with detainings in the } \\
\text { production flow }\end{array}$ \\
\hline & Reducing losses afferent to the time resource \\
\hline & $\begin{array}{l}\text { Reducing costs afferent to equipment } \\
\text { operation }\end{array}$ \\
\hline \multirow{6}{*}{ Chartered accountants } & Determining the cost of auxiliary activities \\
\hline & Reducing labor costs \\
\hline & Reducing indirect costs \\
\hline & Improving the equipment operation time \\
\hline & $\begin{array}{llll}\begin{array}{l}\text { Establishing a standard quota for } \\
\text { consumption of raw materials }\end{array} & & \\
\end{array}$ \\
\hline & Improving the supply with raw materials \\
\hline
\end{tabular}

Source: Created by the authors based on the results of the questionnaire;

And yet, the management accounting-provided information are important, very important to decision making, helping in taking decisions that lead to lower costs and implicitly to higher profit. Besides, all these information cannot be gathered from elsewhere, but from the implementation of management accounting in the economic entities. The information obtained after processing the management accounting-provided data helped the entities management to reduce the labour costs, to improve the instruments operation time, to improve the process of raw material supply, to reduce the work costs, to determine the auxiliary activities costs, etc.

\section{Conclusions}

As a conclusion, we can affirm that, through the detailed analysis performed on the activity, on the internal flow, in terms of value and quantity, related to the expense distribution and the cost development, management accounting is an important component of the accounting information system, with a significant contribution in the management process of an economic entity.

Based on the above mentioned, our opinion is that the organization of a second accounting circuit is necessary, like the financial accounting, as the legislative regulations (Accounting Law no. 82/1991) stipulate the indispensability of its organization. From the empirical studies, we could notice that there are a few companies that organize and conduct management accounting, which is especially common in large companies with production profile. We maintain our opinion, by the fact that, regardless of the activity field, it can have but positive results. Related to the name of the second circuit, management account or managerial accounting, we believe that the latter, i.e. managerial accounting, suits its purpose better, i.e. to provide information necessary for the decisions related to cost reduction. Managerial accounting should not be regarded as useful only to the managers, because the management process does not involve only the management of the economic entities, but it regards each employee of the entity, from the worker to the manager. 
We agree with the above presented issues and sustain the fact that the management accounting must produce and transmit information about the activity costs, information required for the budget and control of the activity, respectively other information imposed by a performing management, information that sustain the elaboration of internal reports and analysis necessary for decision making and for an efficient management of the assets.

The purpose of the research topic "Study on the management accounting organization in Caras-Severin County" is to highlight the importance of the management accounting organization for the development of the economic entities, for the improvement of the profit, in one word, to highlight the importance of the provided information for the decision making process, for the management of the economic entity.

Of the three parts from the research topic, i.e. the management accounting legislation, the importance of the information provided by the management accounting in the decision making process and the one dedicated to the professional accountants, we focused on the second part.

In order to demonstrate the importance of the information provided by the management accounting in the decision making process, we conducted a questionnaire-based applied research, the target group being formed of 50 economic entities belonging to the three parts: microenterprises, small and medium sized enterprises (SMEs) and the large companies, and the obtained data were processed using the SPSS program.

Wanting to know what cost calculation methods are applied in the entities from the target group, we discovered that the modern calculation methods are avoided, but the unpleasant surprise came from the answers received from the professional accountants who declared that they do not no know the name of the applied method.

The most important problem of the professional accountants in the management accounting organization is linked to the incomplete legislation, i.e. to the discrepancies in the law. These problems affect the professional accountant when it comes to organizing the management accounting, in this case to the choice of the cost calculation method that should be implemented.

Other problems concerning the professional accountants in the management accounting organization are related to the lack of the training programs and of the qualified staff, as well as the lack of special software programs used in management accounting.

However, in order to organize the management accounting, the professional accountant turned to the textbooks, to the similar experience of other colleagues.

In terms of the management accounting implementation in the represented economic entities, the problem of gathering information represents the most difficult one, followed by the identification of the calculation method that should be implemented and by the information processing. The most accessible activities were considered the implementation of the calculation method and the transfer of information in accounts; most professional accountants (65\%) use class 6 accounts "Expense accounts" for the organization of the management accounting.

Even if 24 of the 50 subjects told us that the management accounting-provided information are neither important, nor unimportant, however, we recorded 23 situations in which the management accounting helped the entity's management reduce the labor costs, the indirect costs, it led to the improvement of the instrument operation time and of the supply process, etc.

After collecting and processing the data, we believe that the ignorance with which the management accounting is treated, the lack of interest in its organization, the lack of knowledge in this field, the incapacity to see the importance of the information provided by the management accounting for the business development and profit, are based on several factors, and with little goodwill and interest, they could very easily be rectified.

Thus, the legislator should pay more attention to this circuit of accounting, not only to make a few general clarifications. Leaving aside the fact that he himself is the one who declared the management accounting as mandatory, forgetting to write laws and implementation regulations in the field of management accounting, the state would be the first to benefit from the implementation 
of this accounting in the economic entities: maximizing the profit leads to a higher corporate tax, i.e. additional incomes to the State Budget, more workplaces from the developing economic entities, hence more incomes to the Social State Insurance Budget.

Body of Chartered and Licensed Accountants in Romania (BCLAR), which involves many personalities in the field of management accounting, should collaborate with the National Employment Agency for the organization of training courses, with a favourable outcome for both institutions: the reduction of unemployed graduates of economic studies, and why not, the training of the BCLAR members in this field. Let's not forget that this study involved 37 BCLAR members of which 24 chartered accountants and only 15 of them organize management accounting.

\section{References}

1. Bouquin,H., 2004. Comptabilité de gestion, 3 e édition, Ed. Economică, Paris

2. Briciu, S. and Căpuşneanu, S.,2011. Aspecte ale normalizării contabilității manageriale din România la nivel microeconomic, Economie teoretică şi aplicată, Volumul XVIII, No. 3(556), store.ectap.ro/articole/573_ro.pdf

3. Briciu,S., Teiuşan, S., 2006. Management accounting information system, available on-line at www.oeconomica.uab.ro

4. Budugan, D. , Georgescu, I., Berheci, I., Be $\square$ ianu, L., 2007. Management accounting, Ed. CECCAR, Bucureşti

5. Cardo $\square$, I. R., Pete, Ş., 2011, Managerial and cost accounting practices - a Romanian overview, http://anale.steconomiceuoradea.ro/volume /2011/n2/067.pdf

6. Călin, O., Man,M., Nedelcu, M.V., 2008. Managerial Accounting, Ed. Didactică şi pedagogică, Bucureşti

7. Călin, O., Manolescu, M., Tudorache, S., Turlea, E., 2002. Management accounting, Ed. Tribuna Economică, Bucureşti

8. Crețu D., Iova R.A., 2011. The interdependence functions of managerial accounting. Scientific Papers Series Management, Economic Engineering in Agriculture and Rural Development, 11(2)

9. Diaconu P., 2006. Managerial accounting \& Business Plans, Economic Publishing House, Bucharest

10. Diaconu, P., 2002. Managerial accounting, Ed. Economică, Bucureşti.

11. Dumitru, M., Calu, D., 2008. Management accounting and cost calculation, Ed. Contaplus, Ploiești

12. Eierle, B., Wolfgang Sch., 2013. The role of management as a user of accounting information: implications for standard setting. Journal of Accounting and Management Information Systems, available on-line at ideas.repec.org/...ami/journl/v12y2013i2p155189.html

13. Emery, F.E., 1969. Organizational Planning and Control Systems: Teory and Technology, New York, Macmillan

14. Iacob, C., Karim, A. A., 2013, What we want to be the cost?, Munich Personal RePEc Archive, http://mpra.ub.uni-muenchen.de/48606/

15. Jarvenpaa M., 2009. The Institutional Pillars of Management Accounting Function, Journal of Accounting \& Organizational Change, Vol. 5, No. 4

16. Ovidia D., 2013. Basic accounting, course support, available on-line at http://www.svedu.ro/ curs/ bc_dovidia.pdf

17. Pete, Şt., Cardoş I.R., 2011. Tasks and Duties of Professional Managerial Accountants in the Era of Globalization and Technology, Studia Universitatis "Vasile Goldis" Arad Economic Sciences Series, 5(2) 
18. Simon, H.A., 1978. Centralization vs. Decentralization in Organizing the Controller's Departament, New York, Controllership Foundation, 1954, rééd. Houston, Scholars Book Co

19. Warren, S., Parker, L, 2009. „Bean counters or bright young things? Towards the visual study of identity construction among professional accountants", Qualitative Research in Accounting \& Management, Vol. 6, no. 4, http://econpapers.repec.org/article/emeqrampp/default6.htm

20. Zare, I., AgjjehKandi Ojaghi,M., AgjjehKandi Ojaghi,G., 2012. Qualitative Characteristic of Accounting Information in Reported Values of Goodwill and Intangible Assets (Case Study of the Stock Exchange of Iran), Middle East Journal of Scientific Research 11( 1), idosi.org/mejsr/mejsr11(1)12/6.pdf

21. Zare, I., Shahsavari, A., 2012. Ability of Accounting Information to Anticipate Risk, American Journal of Scientific Research, Issue 49, http://americanjournalofscientificresearch.com/ajsr_issues.html

22. Zare, I., Nekounam, J., Pirzad, A., Sedaghatjoo, F., Mosavimoyahar, S., 2013. Role of accounting information systems on relevance of accounting information, Life Science Journal, 10(3s), http://www.lifesciencesite.com

23. Legea nr.82/1991, Accounting law, with subsequent modifications and supplements, updated 2013

24. OMFP nr. 1826/2003 for the approval of the specifications on some measures concerning the management accounting organization 